\title{
Courtroom Questioning Adapted to Psychological Motivations
}

\author{
Haijuan $\mathrm{Hu}$ \\ Correspondence: Hu Haijuan, College of Continuing Education, Guangdong University of Foreign Studies, Guangzhou, \\ China.
}

Received: May 15, 2019 Accepted: Mar. 30, $2020 \quad$ Online Published: May 19, 2020

doi:10.11114/ijce.v3i2.4862 URL: https://doi.org/10.11114/ijce.v3i2.4862

\begin{abstract}
This paper focuses on analyzing courtroom questioning as a dynamic process of adaptation to the psychological motivations, which is complicated by the constantly changing communicative context. By analyzing the data collected from the Chinese courtroom trials, such strategies as repetition, reformulation and juxtaposition are found in the process of questioners' making adaptation to their psychological motivations. By carefully choosing the strategies catering to different psychological motivations, questioners can successfully realize adaptation so as to achieve their specific communicative goals.
\end{abstract}

Keywords: courtroom questioning, psychological motivations, repetition, reformulation and juxtaposition, communicative goals

\section{Introduction}

This paper aims to examine courtroom questioning as a dynamic process of adaptation to the various contextual factors, especially the psychological factors in legal settings. The objectives of this study are (1) to describe the strategies adopted by questioners in courtroom trial, and (2) to examine the complexity, functionality, and dynamics of the strategies in courtroom questioning.

Most previous studies on questions and questioning in courtroom trial have been approached from different perspectives such as rhetoric (Sun \& Zhou 1997, Wang 1999), conversational analysis (Levi \& Walker 1990, Conley \& O'Barr 1998), sociolinguistics (Woodbury 1984, Philips 1987, Walker 1988, Matoesian 1999, 2000; Ehrlich 1999, Eades 2000, to name just a few) and pragmatic analysis (Woodbury 1984, Drew 1992, Ilie 1994, Luchjenbroers 1997, Matsumoto 1999). The rhetorical approach focuses on searching the purpose and functions of courtroom questions; the sociolinguistic approach aims to reveal the connections between social factors and the performance of courtroom questioning; the conversational analysis approach attempts to bring the dynamics of courtroom questioning to the study through the analysis of sequencing of conversational turns; the pragmatic approach is particularly concerned with the function of language use in courtroom questioning.

In courtroom questioning, both the questioner and the respondent will carefully adapt their speech to the constantly changing context to realize their respective communicative needs. All the factors in legal, social and mental world in particular contribute to the linguistic choice of each speaker. Because the decision of each legal case is closely related to the persons concerned, they will make full use of strategies to present their case for their own benefit. As previous studies based on rhetorical, pragmatic, sociolinguistic or conversational analysis fail to illustrate the full complexity of courtroom verbal communication, a more dynamic, systematic and comprehensive approach based on the Adaptation Theory is adopted to study courtroom questioning for the present study.

\section{Conceptual Model for the Adaptation of Courtroom Questioning}

Adaptation Theory first appeared in Pragmatics as a Theory of Linguistic Adaptation (Verschueren 1987), the working document of the International Pragmatics Association (IPrA). The theory proposes that making adaptation is the key to organisms' survival in their process of maintaining the dynamic balance between the environment and themselves. In terms of language using, human being "makes negotiable linguistic choices from a variable range of possibilities in such a way as to approach points of satisfaction for communicative needs" (Verschueren 1999:61) and in the long run contribute to the survival of human beings.

\subsection{Key Notions: Three Properties of Language}

Verschueren (1999:58) claims that language use can be defined as the continuous making of linguistic choices, 
consciously or unconsciously, for language-internal and/or language external reasons, at any level of linguistic form. The idea that using language is a continuous making of linguistic choices is proposed on the basis that language is characterized by variability, negotiability and adaptability. Variability is the property of language which defines the range of possibilities from which choices can be made (Verschueren 1999:59). This feature of language enables language users to make choices. The concept of variability may be associated with what is traditionally called "varieties of language", whether defined geographically, socially, or functionally. Yet, it is meant to cover the entire range of variable options that must be assumed to be accessible to language users for them to be able to make choices. The language used in courtroom questioning makes no exception. Take the following fabricated questions for instance:

(1) (The judge is questioning witness A, whose husband B has been accused of murdering)

审判长: 6 月 3 日晚, 被告/你老公/你爱人/B 是什么时候回家的?

Judge: In the evening of June 3, when did the defendant/your husband/your spouse/B go home?

Here all “被告”, “你老公”, “你爱人” and “B” can be used to refer to the same person, but only “被告” is the appropriate choice in the special institutional setting.

Negotiability is the property of language responsible for the fact that choices are not made mechanically or according to strict rules or fixed form-function relationships, but rather on the basis of highly flexible principles and strategies (ibid:59). The lack of one-to-one correspondence between linguistic form and communicative function does not imply that the relation between them is of a random nature. In fact, quite a number of factors have repercussions on their matching. In the actual course of communication, the speaker needs to consider, consciously or unconsciously, what kind of form-function mapping is the most appropriate. Take the following utterances for example:

(when questioning the defendant or witness)

那个妇女穿什么颜色的祄衫?

(a) What color is the woman's blouse?

那个妇女是不是穿白祄衫?

(b) Was the woman wearing a white blouse or not?

那个妇女穿白祄衫吗?

(c) Was the woman wearing a white blouse?

那个妇女穿白衬衫或者穿黄祄衫?

(d) Was the woman wearing a white blouse or a yellow blouse?

那个妇女不是穿白衬衫吗?

(e) Wasn't the woman wearing a white blouse?

须知那个妇女是穿白衬衫呀? (!)

(f) You should know that the woman was wearing a white blouse? (!)

那个妇女的白祄衫是不是被撕破了(虽然那个妇女根本没穿白祄衫)?

(g) Was the woman's white blouse torn up (even though the woman did not wear a white blouse at all)?

Although the options a-g contain similar propositional content and are equally likely to fulfill the same communicative purposes, they represent different pragmatic strategies. Each strategy derives from a different consideration and produces a different effect. It is up to the speaker to choose a mode of speaking, depending on the contextual configurations involved.

If language use is a process of constant negotiation and renegotiation, how can communication be successful? The possible success of communication lies in the third feature of language. Adaptability is the property of language which enables human beings to make negotiable linguistic choices from a variable range of possibilities in such a way as to approach points of satisfaction for communicative needs (ibid:61).

Variability, negotiability and adaptability are fundamentally interrelated properties of the overall object of investigation for linguistic pragmatics, the meaningful functioning of language. The former two are necessary to the understanding of the third property, which is a higher-order notion. The adaptability of language can be adequately understood if the first two properties of language are understood.

\subsection{Four Angles of Investigation}

Linguistic adaptation can be examined from four inter-related angles for a better pragmatic description and explanation, 
including contextual correlates of adaptation, structural objects of adaptation, dynamics of adaptation, and the salience of the adaptation process. These four angles are in perfect agreement with the linguistic, social, cultural and cognitive elements involved in the dynamic process of language using.

According to Verschueren (1999:66-67) contextual correlates of adaptation include all the ingredients of the communicative context with which linguistic choices have to be interadaptable: language users (utterer and interpreter), mental world (such as personality, emotions, beliefs, desires or wishes, motivations or intentions etc. of language users), social world (such as social settings, institutions, culture, etc.) and physical world (such as time, space, bodily postures, physical appearance, physical conditions, biological property, etc.).

The contextual correlates of adaptation could be sketched as Figure 1(Verschueren 1999:76):

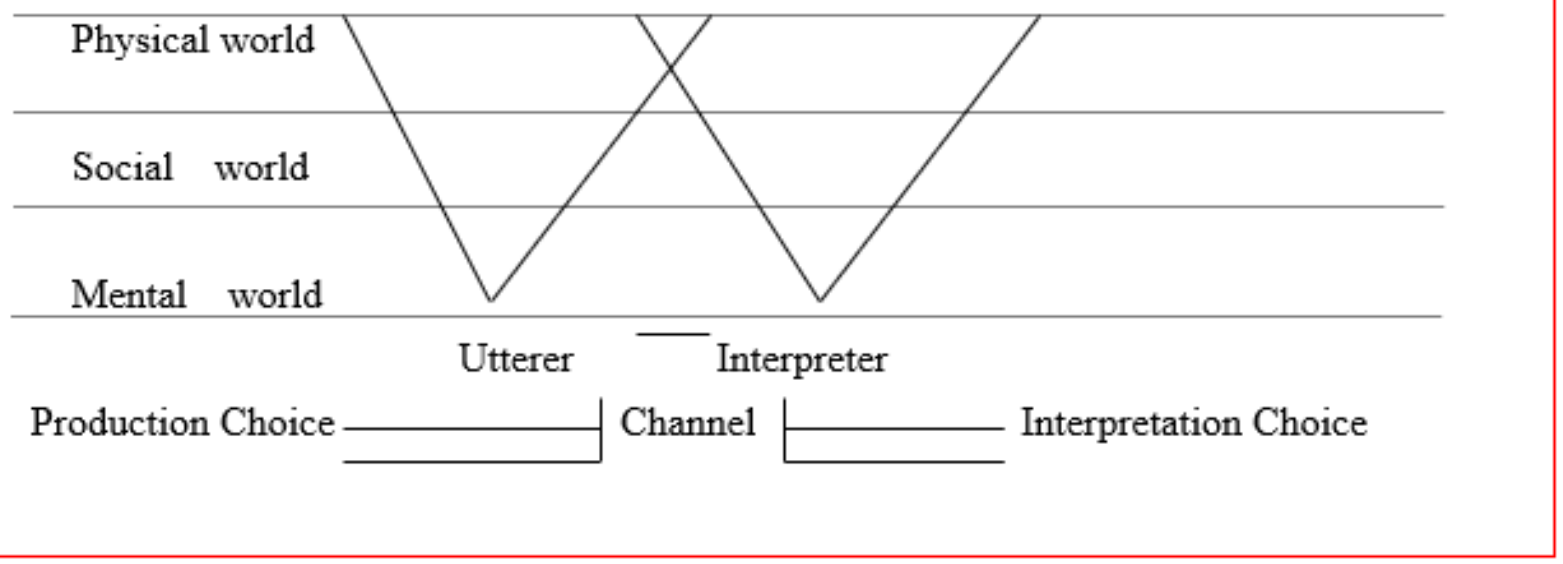

(Linguistic Context)

Figure 1. Contextual Correlates of Adaptability

Secondly, constrained by the communicative context, the choice of linguistic structures should be considered. Since the making of communicative choices takes place at all possible levels of linguistic structure that involve variability of any kind, pragmatic phenomena can be related to any layer or level of structure, from sound feature and phoneme to discourse and beyond, or to any type of interlevel relationship. Involved are not only "structures", but also the principles of "structuring".

Besides, any pragmatic description or explanation must account for the dynamics, the actual process of making choices. The dynamics of meaning generation is located in relation to the temporal dimension of language use and other contextual dimensions, such as social relationships. According to Verschueren, although space is a powerful contextual correlate of adaptability, time clearly imposes more universal constraints on verbal interaction. The dynamics of meaning generation is largely accounted for in terms of strategies employed in the choice-making process.

Lastly, the differences in the salience of the adaptation processes have to be taken into consideration. 'Salience' explores the fact that not all choices are made equally consciously or purposefully. Some are virtually automatic, while others are highly motivated. Three types of mental processes that contribute to the making of linguistic choices are discussed: perception and representation, planning, and memory. Particular attention is paid to meta-pragmatic awareness, namely the reflexive awareness of the linguistic choice-making process.

These four tasks put together are adequate for the description of the three properties of language (i.e. variability, negotiability and adaptability) and, in fact, can be seen as the necessary ingredients of an adequate pragmatic perspective on any given linguistic phenomenon.

Linguistic adaptation can be examined from four inter-related angles for a better pragmatic description and explanation, including contextual correlates of adaptation, structural objects of adaptation, dynamics of adaptation, and the salience of the adaptation process. These four angles are in perfect agreement with the linguistic, social, cultural and cognitive elements involved in the dynamic process of language using.

It is true that courtroom questioning as the result of linguistic choice originates in the questioner's adaptation to the communicative context. Psychological motivations in the present study refer to the speakers' spontaneous motives or intentions behind their courtroom questioning. Courtroom questioning as the questioners' adaptation to the psychological motivations represents the execution of questioning driven by the spontaneous communicative goals. On 
the basis of Adaptation Theory and the review of previous studies on courtroom questioning, a conceptual framework in terms of the factors influencing the choice making process involved in courtroom questioning will be presented for describing, understanding and explaining the complexity, adaptability and functionality of courtroom questioning based upon previous sections.

\section{Data Analysis}

A Chinese criminal trial is different from its Anglo-Saxon counterpart in several respects. The main actors are the judge, the prosecutor and the defense lawyer. There is no jury, but there are three (or actually five) lay judges, who are seated at the front panel together with the professional judge (chairman of the court) and a clerk. The lay judges are elected representatives and usually have a good deal of court experience. Though they normally remain silent during the trial, they take an active part in the private deliberation of the court. It is the usual practice that in China the witness is not physically present during the trial except in some serious cases and their testimony is often read out to the court. The trials are rather informal. Paraphernalia like wigs or other symbolic garments are not used, and hearings are carried out in a rather informal way. The whole procedure is less adversarial than in the Anglo-Saxon system, and the difference between examination and cross-examination, for example concerning types of questions, is not so clear-cut. The judge is often fairly active during hearings. Trials are open to general public, although often (at least in petty cases) there are few or no auditors present.

The study represents an example of qualitative research methodology. The process of study proceeds from observing and collecting naturally occurring data in courtroom trial to their classification and description. All data are transcripts of several trials in criminal courts, randomly chosen from the 2000-2001 period. From the data collected for the present study, such strategies as repetition, reformulation and juxtaposition are found in the process of questioners' making adaptation to their psychological motivations which will be illustrated in the subsequent sections.

\subsection{Repetition}

\subsubsection{Third-Turn Repetition for the Benefit of the Collegiate Bench}

Since the overhearing audience is unable to exhibit (at least vocally) their understanding of an answer, the questioner may not be sure whether the collegiate bench or jury has fully appreciated the force or significance of a witness' prior response. The defendant's conviction or acquittal depends on the collegiate bench or jury members' construction of what happened (Luchjenbroers 1993); hence, the "third turn" or "follow-up" (i.e. the question after a question-answer sequence) is an opportunity for the questioner to "emphasize" a point in the respondent's answer by repeating all or part of that answer and such (partial) repeats are formed as questions which check or confirm the witness' response.

In everyday conversations, partial repeats of what the prior speaker just said commonly indicate that the recipient has doubts about the correctness of what was said: they are used to initiate repair, to invite the speaker to "think again" and correct something in the previous utterances. But in courtroom examination, partial repeats are not generally associated with questioners' doubt about prior answers, nor with respondents' self-repair; instead, the questioner's repetition of the respondents' prior answer functions to highlight the answer for the benefit of the non-participating audience, that is, it helps the collegiate bench or jury's comprehension. Extract (1) is adapted from Wang (1999).

(1).

(The prosecutor accuses A of premeditated killing with a knife bought on May $5^{\text {th }}$. The defense lawyer is questioning A as follows:)

Q: 你用于杀死被害人的木柄单刀尖刀, 在你购买它时, 到底是用来准备杀害被害人的, 还是用来作别的用呢?

Q: Why did you buy the single blade knife with wooden handle, which you used to kill the victim? Did you buy it to kill the victim, or for other reason?

A：我买这把刀是卖马蹄时用来削给别人吃的。

A: I bought the knife to peel water chestnuts for customers when I was selling them.

(The prosecutor is cross-examining the witness.)

$\mathrm{Q}$ : 你当时看见 $\mathrm{A}$ 拿出一把什么样的刀?

Q: What kind of knife did you see when A took it out?

$\mathrm{A}$ : 是一把带锈的木柄单刃尖刀。

A: It's a rusted single blade knife with wooden handle.

$\mathrm{Q}$ : 是带锈的吗?

Q: Was it rusty? 
A: 是, 刀刃上几乎全是锈。

A: Yes, there are rusts all over the blade.

Q: 难道会有人吃用一把生锈的刀削的马蹄吗?

Q: Will anybody eat water chestnuts peeled with a rusted knife?

The defendant is accused of premeditated killing with a knife bought on May $5^{\text {th }}$. In court he tries to find excuses to minimize his penalty, so he claims that the knife was bought to peel the water chestnut for his customers. In courtroom interaction, the intended audience is the judge and the collegiate bench. After the defendant presents the answer, the audience would doubt whether the prosecutor's accusation - the defendant's premeditated killing — is reasonable. In order to remove the doubt from their mind, the prosecutor summons a witness to the court and cross-examines him about the physical appearance of the knife, and the witness testifies that the knife is “一把带锈的木柄单刃尖刀(It's a rusty knife)”. Then the prosecutor quickly repeats the information: “是带锈的吗”(Is it rusty)?” in the third turn, and repetition is further employed in the following third turn “难道会有人吃用一把生锈的刀削的马蹄吗?” after the confirmation from the witness “是, 刀刃上几乎全是锈”. By repeating the information “带锈, 生锈 (rusty)” in his question, he not only seeks confirmation from the witness, but also wants to draw the attention of the audience, especially the judge and the collegiate bench. Actually the strategic use of repetition in the question is well adapted to the puzzled audience, after they hear the prosecutor's question about the physical appearance of the knife, they must be wondering about the intention of the questioner: Why does the prosecutor ask the physical appearance of the knife? Does the physical appearance have anything to do with the case? The repeated use of witness testimony in the question together with the witness confirmation makes the audience especially the judge and the collegiate bench realize that the defendant is lying, because nobody will eat the water chestnut peeled with a rusty knife. In a word, motivated by the puzzled audience and the cunning defendant, the prosecutor carefully formulates his question in the third turn by choosing the strategy of repeating the relevant testimony, which satisfies his communicative needs - to discredit the fabricated answer of the defendant and to justify his own accusation.

Extract (2), taken from the criminal case about burning a private car, is another good example of third turn repetition:

(2).

公: 恩。有没有这个---脚套儿? followup+Q（正反）

Prosecutor: Well. Were there any podothecae?

张: 脚套儿他戴着一副, 后来他戴着的。Answer=imply+supply

Zhang: There was a pair of podothecae that he was wearing. He put on the podothecae later on.

公: 后来他戴着了?

Prosecutor: He put on the podothecae later on?

张: 恩

Zhang: Yes.

公: 什么时间戴的? Q-when

Prosecutor: When did he put them on?

张: 他到现场以后, 离那车库还有--- (3s) 还有还有个一百多米吧。Answer=comply

Zhang: He put them on after he went to the spot, somewhere about 100 meters away from the garage.

公: 还有一百多米, 是吧? Q-tag

Prosecutor: It was about 100 meters away, isn't it?

张: 恩 answer=comply

Zhang: Yes.

公: 谁帮他戴的? Q-who

Prosecutor: Who helped him put on the podothecae?

张: 他自己戴的, 后来那个有个带儿让我给他系着。Answer=comply+supply

Zhang: He put them on by himself, and later he asked me to help him tie the string of the podothecae.

公: 行, 有个带儿你帮他系着,

Prosecutor: All right, you helped him tie the string of the podothecae. 
张: 啊

Zhang: Yes.

公: 是吧? Q-tag

Prosecutor: Did you?

张: $\quad$ 是 answer $=$ comply $\quad($ confirm $)$

Zhang: Yes, I did.

In courtroom questioning, all questions have to be tailored to the statutory description of the crime (Philips 1987:92). In order to get the factual basis sufficient to convict the defendant as a joint criminal, the questioning begins with two questions: Did they take the podotheca on their way to burning the car? And when did his brother put it on? Catering to the prosecution of a joint crime, “谁帮他戴的(Who helped him put on the podotheca)?" is further examined. In the subsequent answer, the defendant admits that “他自己戴的, 后来那个有个带儿让我给他系着(He put it on by himself, and later he asked me to help him tie the string of the podotheca)", which is a very important testimony favorable to the prosecution. The defendant contributed to the crime by helping his brother put on the podotheca as an important criminal tool, so the crime was committed by the defendant and his brother jointly and intentionally. Adapted to the psychological motivation of prosecuting the defendant as a joint criminal, the prosecutor's third-turn repetition of the defendant's prior answer “行, 有个带儿你帮他系着 (All right, you helped him tie the string of the podotheca)” appears recurrent in examination, functioning to highlight the answer for the benefit of the collegiate bench. Because the final conviction or acquittal of the defendant mostly depends on the collegiate bench's construction of what happened, the repeated information can attract their attention and therefore the testimony favorable to the prosecution will leave a deep impression on the members of the collegiate bench.

\subsubsection{A Question-Cycle to Elicit Damaging Testimony}

In addition, Lane (cited from Luchjenbroers 1993:151) observes that during cross-examination, the counsel often asks the same question a number of times, although using (slightly) different words, in an attempt to highlight weaknesses in the victim's version of the events. It is this process that Lane refers to as 'question cycle'. Shuy (cited from Luchjenbroers 1993:151) also refers to the same phenomenon in natural discourse as 'topic recycling', i.e. bringing a subject up again and again. Shuy further explains that topics tend not to be recycled over and over again if the listener gives a satisfactory response the first time, and a failure to do so may thus be construed as evading the issue.

It is common for the defendant to be evasive when presenting any testimony which is detrimental to his defense. In order to obtain the desired answer, the questioner often adapts his questioning to a question cycle as illustrated in the following example.

(3).

Q1： \|你怎么 $\perp$ 你们俩怎么去的？Q-how

Q1: How did you get there?

A1: 我们俩坐车去的。Answer=comply

A1: We went there by car.

Q2: 坐车去的? 。

Q2: You went there by car?

A2: 《啊

A2: Yes.

Q3: ॥谁开车? Q-who

Q2: Who drove the car?

A3: 他开车。Answer=comply

A3: It's him.

Q4: 什么车? Q-what

Q4: What kind of car?

A4:二零车。Answer=comply

Two zero car (brand name of the car). 


\section{Q5: 谁的车? Q-whose}

Q5: Whose car?

A5: 就是他的吧。 Tentative answer with particle “吧”

A5: Maybe his car.

Q6: 车主是谁? Q-who

Q6: Who is the owner of the car?

A6: 车主, 车主是---

A6: The owner of the car is...

Q7: $\boldsymbol{\nabla}$ 是不是你的? $\mathrm{Q}$ (正反)

Q7: Is it yours?

A7: 车主是我的。车主是 $\perp$ 那车是我给我媳妇买的, 后来煤窑没车, 就给他\|了。Answer $=$ comply + supply

A7: The car is mine. I bought the car for my wife, but later because there is no car in the coal mine, I gave it to him.

Q8: ॥车主是不是你的? Q(正反)

Q8: Are you the owner of the car?

A8: 是我的。Answer $=$ comply

A8: Yes, it's mine.

Extract (3) is taken from the same case about burning the car. When questioning the defendant, the prosecutor wants to prove that the defendant provided the means of transportation for them to burn the car, so he is closely related to the crime and therefore should be responsible for the crime. In order to minimize his penalty, the defendant tries to be evasive and shape the story for his own benefit. Catering to the psychological motivation of discrediting the defendant, the prosecutor employs the strategy of question cycle in the following questioning “谁开车 (Who drove the car) ?, 什 么车 (What kind of car)? 谁的车 (Whose car)? 车主是谁 (Who is the owner of the car)? 是不是你的 (Is it yours)? 车主是不是你的 (Are you the owner of the car)? ”. All the above questions boil down to one point: who provides the vehicle for them to burn the car? Out of the instinct of defending himself, each time the defendant tries to hide the truth with some tentative answer as A5 “就是他的吧” with a particle “吧”; meanwhile, out of respect for and fear of the solemnity of the law, he has to tell the truth in A7 “车主是我的 (The car is mine)" with some explanations attempting to excuse himself “车主是 $\perp$ 那车是我给我媳妇买的, 后来煤窑没车, 就给他川了(I bought the car for my wife, but later because there is no car in the coal mine, I gave it to him)". Unsatisfied with the evasive answer, the prosecutor adapts his questioning by interrupting the defendant and asking him with a leading question “车主是不是你的 (Are you the owner of the car)? ". Having been driven into a tight corner, the defendant has no choice but to confess with a self-incriminating “是我的 (Yes, it's mine)". By adapting the questioning to the psychological motivation with a question cycle, the prosecutor finally succeeds in finding out the truth.

\subsection{Reformulation}

Reformulation is a term specifically designed to refer to the process of rewording or rephrasing whereby some psychological factors can be adequately adapted to.

Questioners need to establish themselves as authoritative and trustworthy. To this end, they make use of technical legalese to establish authority (cited from Luchjenbroers 1993:139). But in order to mobilize cooperation, questioners in some cases reformulate their questions with colloquial language which makes the questioning more conversation-like. As Shuy (1998:188-189) states:

"In a conversation, both parties become equal, a fact that encourages self-revelation... Therefore, if the goal is to get the suspect to self-generate information, even guilt, it is useful to make the communication event as much like a conversation as possible, where equal power and status permit such self-generation."

The following example is a case in points.

(4).

辩：你再回答下一个问题。你什么时知道这个 $\perp$ 那天出去去烧车呀? Preface (metastatement) $+\mathrm{Q}$ (when)

Defender: Answer the next question. When did you know you were going to burn the car that day?

张: 就当天我才知道。Answer=comply

Zhang: I knew that on the very day we did it. 
辩: 当天才知道? 。

Defender: You didn't know until that day?

张: 恩

Zhang: Yes.

辩: 你知道之后你为什么不离开现场中断犯罪呀? precursor (time) $+\mathrm{Q}$ (why)

Defender: Why didn't you leave the spot and discontinue the crime after you find out you were going to burn the car?

张: 我没听清你的话, 请你再陈述一遍。(request for repetition)

Zhang: I can't hear you clearly. Please say that again.

辩: 啊, 我就是说呀,

Defender: I mean...

张: 恩

Zhang: Yes.

辩: 你已经知道了, 说是要去烧车, 啊, 毁坏财产, 那你为什么没有, 啊, 自己回来, 呃, 中断这件事情呢? (reformulating the question with everyday expressions“自己回来” and “这件事情”for legal terms“离开现场” for “犯罪” and amplifying the precursor with “去烧车” and “毁坏财产”)

Defender: Since you had noticed that you were to burn the car, to destroy the property. Why didn't you come back by yourself? Why didn't you discontinue this action?

张: 当时他跟我说, 咱们就这么忪, 让人家欺负, 替他交钱。那个你, 你跟我去吧, 出了事儿有我一个人顶着。 你别的甭管, 你就管帮我看看人就行了。Answer=comply

Zhang: At that time, he told me that we were so timid that he bullied us and asked us to pay for him. He asked me to go out with him and he would take full responsibility if any trouble occurred. He said that the only thing I had to do was to check if there was anybody coming.

辩：恩

Defender: All right.

The above extract is taken from the direct examination between the defendant and the defense lawyer. As is common with lawyers in examination-in-chief, he tries to provide the defendant with the chance to justify his action by asking the question “你知道之后你为什么不离开现场中断犯罪呀 (Why didn't you leave the spot and discontinue the crime after you knew you were going to burn the car) ?". Catering to the solemn atmosphere and his institutional identity, the lawyer carefully formulates his question with legal terms “离开现场 (leave the spot)" and “中断犯罪 (discontinue the crime)", which sound more authoritative and trustworthy. But the defendant, as a peasant with secondary schooling, failed to understand the question. So instead of presenting favorable testimony to defend himself, he has to request for repetition. In the following turn, “你已经知道了, 说是要去烧车, 啊, 毁坏财产, 那你为什么没有, 啊, 自己回来, 吃, 中断这件事情呢?”, an informal and conversational-like register is employed with an attempt to facilitate comprehension. The lawyer reformulates the question with everyday expressions: substituting"自己回来 (come back by yourself)" and “这件事情 (this action)” for legal terms“离开现场 (leave the spot)" and “犯罪(committing the crime)", and amplifying the precursor with “去烧车 (to burn the car)" and “毁坏财产 (destroy the property)". Compared with the first version, it sounds more conversational-like, which can put the defendant at ease and ensure his full understanding of the question. As a result, the questioner succeeds in obtaining the desired answer. Without the psychological adaptation, the cooperation between the defendant and his lawyer will be harmed and therefore the defendant will lose the opportunity to excuse himself.

\subsection{Juxtaposition}

Apart from repetition and reformulation strategies, we find a third strategy, i.e. juxtaposition. Juxtaposition in this study refers to statements put next to each other aimed at showing their inconsistency or forming a contrast. It is another strategy employed by the questioner to realize his psychological adaptation so as to upset the fabricated testimony in courtroom examination.

The management of creating the impression of unreliability and inconsistency is one central purpose of questioning in cross-examination. By juxtaposing inconsistent or self-contradictory propositions, the questioner can successfully adjust to his psychological motivation by revealing inconsistencies between parts of the testimony, or between the testimony and what may actually has occurred. Luchjenbroers (1993:147) discusses a similar phenomenon as follows: 
'counsel might pursue a line of questioning that will result in incongruity between two adjacent pieces of information which raises doubts about the witness's truth and reliability'

(5).

\section{$\mathrm{Q} 1$ ：二零零.零年九月三十号, 你在公安机关, 你怎么供述的你·还记得吗? $\mathrm{Q}-\mathrm{y} / \mathrm{n}$}

Q1: On September $30^{\text {th }}, 2000$, you were in the police station. Do you remember your statement at that time?

$\mathrm{A} 1$ : 九月三十号 $(5 \mathrm{~s})$

A1: September $30^{\text {th }}$.

Q2：你还记得吗? Q-y/n

Q2: Do you remember?

A2: 九月三十号---

A2: September $30^{\text {th }}$.

Q3：嗯? 。

Q3: Yes?

A3：九月三十号我填的捕票。Reply (supply)

A3: The arrest warrant was issued on September $30^{\text {th. }}$

Q4：恩？你怎么供述的？我问你， 世就这个情节。Preface $(\mathrm{Q})+\mathrm{Q}$ (what)+residue (metastatement+focus)

Q4: So? What was your statement? That is what I'm asking about.

A4：怎么供述的? 就这么供述的。Preface (Q)+answer (?)

A4: What was my statement? I made the statement like that.

Q5：现在我跟你宣读一下，二零零年九月三十号你的供述。

Q5: Now I will read for you the statement you made on September $30^{\text {th }}, 2000$.

A5: 啊

A5: Ok.

Q6：啊！“今年三月二号晚上，我和张文刚从房山（---2）回来到家，张文刚说，昨天看电视了，预报有风，咱 们把他家车烧了，东西准备好了，出事儿我担着，（2s）你跟我看人就行。”

Q6: Well. "In the evening of March $2^{\text {nd }}$ this year, I went back home with Zhang Wengang from Fangshan. Zhang Wengang said, 'I watched TV yesterday, and it'll be windy according to the broadcast. Let's go and burn his car. Everything's ready. I'll take full responsibility if there is any trouble. You only have to check if there is anybody coming."

A6: 是, 当时他比是这么说的。

A6: Yes. That's what he said at that time.

Q7: 嗯? Q-really

Q7: Really?

A7: 他说今天有风。

A7: He said, "it'll be windy today."

Q8: 那刚才问你, 你为什么说是你到了现场以后你才知道啊? Q-why

Q8: When I asked you just now, why did you say that you didn't know that until you arrived at the spot?

A8: 到、到现场我就知道他确切烧烧人家车去了,

A8: When we got to the spot, I knew he was really going to burn his car.

Q9: 嗯? Q-really

Q9: Really?

A9: 烧那个张有名家川车了

A9: He was to burn Zhang Youming's car.

Q10： \|是去现场之前知道的还是到、到现场你才知道的? Q-alternative 
Q10: You know that before you went there, or you find it out after you get to the spot?

A10: 到车上他就跟我说过, 到现场还跟我说过。Answer (comply)

A10: He told me when we got into the car, and he told me again after we arrived at the spot.

Q11：在家走的时候你知道不知道? Q (正反)

Q11: Did you know that when you left home?

A11: 到家走的时候他也跟我说过。Answer (imply)

(6s)

A11: He told me when we left home.

Q12: 走时你知道吧? Q-y/n (declarative)

You did know that when you left home, right?

A12: 走时他跟我说过, 我还劝过他川（--- ) Answer (imply)

A12: He told me when we left home, and I tried to persuade him.

Q13: 川从他走的时候你知道不知道干嘛去? Q-y/n

Q13: Did you know what you were going to do when he left?

A13：他说烧人家车去。Answer (imply)

A13: He said he was going to burn the car.

Q14: 你知道不知道? 我问你 Q (正反)+residue (metastatement)

Q14: I ask you: did you know that?

A14: 知道啊。Answer (comply)

A14: Yes, I knew.

Q15: 知道? 。

Q15: You knew that?

A15: 嗯

A15: Yes.

The defendant claims that he did not know they were going to burn the car until he reached the spot. The purpose of the prosecutor in this extract is to rebut the invented testimony of the defendant. In Q1 the prosecutor reminds the defendant if he still remembers what he confessed in the public security organization, which implies that the defendant did not tell the truth. In order to avoid the self-incrimination, the defendant had to wander away from the topic with an answer irrelevant to the question. So, the prosecutor immediately draws him back to the focus by saying: "I ask you what you confessed about this plot?" but he insists on presenting the same story. In the presence of the stubborn defendant, the prosecutor adapts the questioning by juxtaposing the fabricated story with his earlier testimony in the public security organization which indicates that on that very night his brother had already told him what they were going to do. After the inconsistent testimony is frozen, the prosecutor begins to impeach the defendant: “那刚才问你, 你为什么说是你 到了现场以后你才知道啊 (Then why did you claim that you didn't know anything until you reached the spot)?” In the end, the defendant had to clothe his answer with some hedges “确切 (exactly)” and “烧人家车 (burn other's car)”, as shown in A8 and A9, and confesses that before he got to the spot he had already known they went to burn other's car. The following questioning focuses on one point: Did he know they were going to burn the car before he left for the spot? Finally, he did confess his knowledge about their preplanned crime.

In this part of the examination, the contradictory juxtaposition is the most important strategy for the prosecutor to realize his psychological adaptation so as to achieve his communicative purpose, i.e. to discredit the invented story and justify his prosecution. Contradictory juxtaposition as an important adaptation strategy can be further illustrated in the following extract (cited from Jiang 2001):

(6).

Q1: 按照你的自诉状, 邵某和她妹妹两个人一起打你, 是吗?

Q1: According to your Bill of Private Prosecution, Shao and her younger sister beat you together. Is that right?

A1: 是的。 
A1: Yes.

Q2: 她们打你时, 站在什么位置?

Q2: Where did they stand when they beat you?

A2: 邵某站在我前面, 她用手抓住我的头发。她妹妹站在我身后。

A2: Shan stood in front of me, and she caught my hair with her hand. Her sister stood behind me.

$\mathrm{Q} 3$ ：郡某站在你左侧还是右侧？

Q3: Did Shao stand on your left or right?

$\mathrm{A} 3$ : 左侧。

A3: On my left side.

Q4: 是左手抓住你的头发, 还是右手抓住你的头发?

Q4: Did she catch your hair with her left hand or right hand

A4: ...... (沉默片刻) ......左手。

A4: ...(silent)...Left hand.

Q5: 邵某打你用的是哪只手?

Q5: With which hand did Shao beat you?

A5: 右手。

A5: Right hand.

Q6: 用什么打你的?

Q6: What did she use to beat you?

A6: 用砖块。

A6: She beat me with a brick.

Q7: 邵某打你时, 你是站着还是蹲着?

Q7: Were you standing or squatting when Shao beat you?

A7: 站着, 她以砖头将我打昏过去。

A7: I stood there until she knocked me out with the brick.

Q8：她站在你对面左侧, 左手抓住你头发, 右手怎么会打到你右耳部呢?

Q8: She stood face to face with you on your left side with her left hand catching your hair, how could she beat you on your right ear with her right hand?

A8：...... 反正是她打的！

A8: Anyway it's her who beat me.

The plaintiff claims that Shao hurt him on the right ear with her right hand. In order to discredit the plaintiff, the questioner asks detailed questions about the physical position of each party concerned on the scene. Bombarded by the series of questions “她们打你时, 站在什么位置 (Where did they stand when they beat you)? 邵某站在你左侧还是 右侧 ( Did Shao stand on your left or right)? 是左手抓住你的头发, 还是右手抓住你的头发 (Did she catch your hair with her left hand or right hand)? 郡某打你用的是哪只手 (With which hand did Shao beat you)? ”, the plaintiff did not have enough time to calculate his story, so self-contradiction occurred in his testimony. Catering to the purpose of discrediting the plaintiff, the shrewd questioner adapts his questioning by juxtaposing the testimony with a rhetoric question “她站在你对面左侧, 左手抓住你头发, 右手怎么会打到你右耳部呢 (She stood face to face with you on your left side with her left hand catching your hair, how could she beat you on your right ear with her right hand) ?", which is actually a powerful impeachment. By juxtaposing the contradictory testimony, the questioner successfully accommodates to the psychological motivation; therefore, the communicative purpose of discrediting the plaintiff is achieved.

\section{Conclusion and Discussion}

The above analysis shows that courtroom questioning as a dynamic process of adaptation to the psychological motivations is rather complicated because of the constantly changing communicative context. In order to mobilize cooperation or discredit the testimony, different strategies are employed in the process of questioners' making 
adaptation to their psychological motivations. The following strategies were found in the dynamic choice making process: repetition, reformulation and juxtaposition. From the data collected for the present study, we discovered that repetition is frequently employed as a strategy to achieve the communicative goals, which includes third-turn repetition for the benefit of the non-participating audience and a question cycle to elicit confession. Reformulation, as another important strategy, is carefully chosen to realize adaptation so as to either facilitate comprehension in direct examination or elicit damaging testimony in cross-examination. Juxtaposition is an important adaptive strategy often used to discredit the respondent by formulating a contrast or contradiction. By carefully choosing the above strategies catering to different psychological motivations, questioners can successfully realize adaptation so as to achieve their specific communicative goals.

The adaptation model for the analysis of courtroom questioning put forward in the present study was the result of application and development of Verschueren's Adaptation Theory based on the careful review and analysis of the existing models' inability to unveil the intricacy and dynamics of the phenomenon under investigation. The examination of courtroom questioning as a dynamic choice making process and the evaluation of various functions courtroom questioning can perform were therefore a natural consequence of this particular approach. Furthermore, theoretical framework established in this study may pave the way for future research into the pragmatic functions of other types of institutional questioning. Only such a comprehensive approach may succeed where traditional linguistics failed, namely in analyzing courtroom questioning as a dynamic choice making process, whose subtlety and full complexity are impossible to capture from any previous perspectives.

Besides the above theoretical implications, this study is also of practical significance. Firstly, the study is conducive to the understanding of the operation of courtroom questioning in general and Chinese courtroom questioning in particular. The detailed analysis of procedural adaptation presents a clear picture about the steps Chinese courtroom trial should observe. Secondly, the study of the dynamic process of courtroom questioning also has some implications for the resolution of civil disputes and the prosecution and defense of criminal cases. Only when questioners in courtroom questioning as other speakers in verbal communication adapt to the constantly changing communicative contexts, can they successfully achieve their communicative goals. Compared with the speakers in general communication, questioners in courtroom questioning are invested with considerable power so they can resort to their institutional power to bring the respondent under control. The investigation into the psychological adaptation can shed some light on the art and intricacy of courtroom questioning. Different strategies depicted in this study can be employed by the questioner to facilitate cooperation or impeach the fabricated testimony.

Although the present study has captured the dynamics and some strategies of courtroom questioning via the analysis of the dynamic process of adaptation, there are certain limitations imposed upon by the nature of the data used in this study. These include the absence of supra-segmental information, such as pauses, contractions and intonational information that are edited out of court transcripts. Additionally, the role of non-verbal behavior (i.e., features of face-to-face contact, such as gaze, nods, and eye-direction) is necessarily ignored when dealing with legal transcripts. It must be noted that besides language itself, paralinguistic features also convey meanings in verbal communication and therefore influence questioners' linguistic choices. In this final section, we wind up our discussion by briefly pointing out directions for future research. One direction future research might take is to search for more factors (such as the established morals, personality and educational background) which also influence questioners' linguistic choices in the dynamic process of courtroom questioning.

\section{References}

Conley, J., \& O'Barr, W. (1998). Just Words: Law, Language, and Power. The University of Chicago Press.

Drew, P. (1992). Contested Evidence in Courtroom Cross-examination. Talk at Work: Interaction in Institutional Setting. Cambridge University Press.

Ehrlich, S. (1999). Communities of practice, gender, and the representation of sexual assault. Language in Society, 28, 239-256. https://doi.org/10.1017/S0047404599002067

Hu, H. J. (2004). A General Review of Courtroom Discourse. Journal of Guangdong University of Foreign Studies, 1, $8-11$.

Hu, H. J. (2019). Courtroom Questioning Adapted to Institutional Power. International Journal of Contemporary Education, 2(1), 26-32. https://doi.org/10.11114/ijce.v2i1.4050

Hu, H. J. (2019). Courtroom Questioning Adapted to Legal Procedures. Canadian Centre of Science and Education, 12(1), 7-17. https://doi.org/10.5539/elt.v12n1p7

Ilie, C. (1994). What Else Can I Tell You? A Pragmatic Study of English Rhetorical Questions as Discursive and Argumentative Acts. Almqvist \& Wiksell International Stockholm, Sweden. 
Levi, J., \& Walker, A. (1990). Language in the Judicial Process. New York: Plenum Press. https://doi.org/10.1007/978-1-4899-3719-3

Liao, M. Z. (2003). An Interactive Study on Courtroom Questions and Answers, [M], Law Press.

Luchjenbroers, J. (1993). Pragmatic Inference in Language Processing. unpublished PhD Dissertation. La Trobe University, Australia.

Luchjenbroers, J. (1997). 'In your own words...': Questions and Answers in a Supreme Court Trial. Journal of Pragmatics, 27, 477-503. https://doi.org/10.1016/S0378-2166(96)00033-1

Matoesian, G. (2000). Intertextual Authority in Reported Speech: Production Media in the Kennedy Smith rape trial. Journal of Pragmatics, 32, 879-914. https://doi.org/10.1016/S0378-2166(99)00080-6

Matoesian, G. M. (1999). The Grammaticalization of Participant Roles in the Constitution of Expert Identity. Language in Society, 28, 491-521. https://doi.org/10.1017/S0047404599004017

Matsumoto, K. (1999). And-prefaced Questions in Institutional Discourse. Linguistics, 37(2), 251-274. https://doi.org/10.1515/ling.37.2.251

Philips, S. (1987). On the Use of Wh-questions in American Courtroom Discourse: A Study of the Relation between Language Form and Language Function. Power through Discourse. edited by Leah Kedar, 83-111, Norwood, NJ: Ablex.

Ran, Y. P. (2008). A Study on the Interpersonal Pragmatic Function of Rhetorical Questions from the perspective of Linguistic Adaptation [J], Modern Foreign Languages.

Shuy, R. (1998). The Language of Confession, Interrogation, and Deception. Sage Publications, Inc.

Sun, Y. H., \& Zhou, G. Y. (1997). Forensic Linguistics[M], China University of Political Science and Law Press.

Verschueren, J. (1999). Understanding Pragmatics. Edward Arnold Limited.

Wang, J. (1999). A Study on Legal Language, [M], Guangdong Education Publishing House.

Woodbury, H. (1984). The Strategic Use of Questions in Court. Semiotica, 48(3/4), 197-228. https://doi.org/10.1515/semi.1984.48.3-4.197

Wu, W. P. (1995). Chinese Evidence versus the Institutionalized Power of English. Forensic Linguistics. 2, 154-167. https://doi.org/10.1558/ijsll.v2i2.154

Yu, G. D. (2002). A Pragmatic Analysis of Code Switching in China: An Adaptation Approach. Shanxi People's Press.

Yuan, C. Y. (2010). The Covert Persuasive Power of the Rhetoric Questions in Lawyers' Defending Arguments, Contemporary Rhetoric.

Zhao, J. F. (2007). Legal Speech Acts and Linguistic Strategies. Journal of Guangdong University of Foreign Studies, 1, $8-11$.

\section{Copyrights}

Copyright for this article is retained by the author(s), with first publication rights granted to the journal.

This is an open-access article distributed under the terms and conditions of the Creative Commons Attribution license which permits unrestricted use, distribution, and reproduction in any medium, provided the original work is properly cited. 